\title{
Description of two new Ogma Southern, 1914 species (Nemata: Criconematoidea) with a list of plant-parasitic nematode species from Natal
}

\section{ESTHER VAN DEN BERG}

Van den Berg. Esther. 1992. Description of two new Ogma Southern. 1914 species ( Nemata: Criconematoidea) with a list of plant-parasitic nematode species from Natal. Koedoe 35(1): 9-18. Pretoria. ISSN $0075-6458$.

\begin{abstract}
Two new $O$ gma Southern. 1914 species are described and figured from Giant s Castle Nature Reserve, Kamberg Nature Reserve and the Royal Natal National Park. Ogma naomiae spec. nov. females are characterised by having 10 to 12 longitudinal rows of scales on 63 to 69 retrorse body annuli; scales haphazardly arranged on first nine to 10 annuli: scales mostly with two projections, becoming longer toward tail end; all scales with minute protuberances on outer edges; lip region with one annulus with a greater diameter than first body annulus. Juveniles with 14 to 16 longitudinal rows of scales on 73 to 76 retrorse body annuli; each scale bearing five to seven sharply pointed processes: one lip annulus with an equal diameter to first body annulus. Ogma ueckermanni spec. nov. females are characterised by eight longitudinal rows of rounded scales on 60 to 67 body annuli becoming longer toward tail tip where they bear two, three or four-pronged processes: roughly sculptured recessed part of annulus extends to follow the outline of the scale almost forming a pillar between two succeeding scales; one lip annulus with a greater diameter than first body annulus; raised labial area with six pseudolips and no submedian lobes: margin of lip annulus with rounded tooth-like projections: stylet 49.3 to $60.7 \mu \mathrm{m}$ long. A list is given of the 16 known plant-parasitic nematodes found in these areas.
\end{abstract}

Key Words: Giant's Castle and Kamberg nature reserves. Ogma. plant-parasitic nematodes. Royal Natal National Park, taxonomy.

Esther ran den Berg. National Collection of Nematodes. Biosystematics Division. Plant Protection Research Institute. Private Bag X134. Pretoria.000) / Republic of South Africa.

\section{Introduction}

During a collecting trip by the Acarology Section of the Plant Protection Research Institute in 1990, 13 soil samples were simultaneously collected in the Giant's Castle and Kamberg nature reserves and the Royal Natal National Park to check for plant-parasitic nematodes. Sixteen known species were found (Table 1). Single specimens, probably representing new species of different genera were also found but could not be described because of inadequate material. Specimens of two unknown $O$ gma species were found and are here-in described as new.

\section{Material and Methods}

All measurements and drawings were made from specimens killed by the gradual application of heat. preserved in TAF and mounted in glycerine according to the slow method of Goodey (1951). SEM photographs were taken from specimens preserved in TAF. dehydrated in increasing concentrations of amyl ace- tate in pure alcohol and finally into pure amyl acetate. Critical point drying and gold/paladium coating ( 2.5 $\mathrm{nm}$ ) were carried out in the conventional way and the specimens viewed with a JEOL-35 stereoscan microscope at $15 \mathrm{kV}$.

The following specimens are deposited in the collection of the Laboratoire des Vers, Museum national d'Histoire naturelle. Paris, France: Ogma naomiac' spec. nov. (nine paratype females) and $O$. weckermanni spec. nov. (three paratype females). All other specimens are deposited in the National Collection of Nematodes, Biosystematics Division. Plant Protection Research Institute. Private Bag X134. Pretoria 0001 . South Africa.

\section{Taxonomy}

Ogma naomiae spec. nov. (Figs 1 - 3)

\section{Measurements}

Holotype female - Muller's Pass: L $=489$ $\mu \mathrm{m} ; \mathrm{a}=8,2 ; \mathrm{b}=3,9 ; \mathrm{V}=95 ;$ stylet $=87,1$ 
Table 1.

Plant-parasitic nematodes found in Natal

\begin{tabular}{|c|c|c|c|}
\hline Nematode & $\begin{array}{l}\text { Giant's Castle } \\
\text { Nature Reserve } \\
\text { 3 samples }\end{array}$ & $\begin{array}{l}\text { Kamberg } \\
\text { Nature Reserve } \\
1 \text { sample }\end{array}$ & $\begin{array}{l}\text { Royal Natal } \\
\text { National Park } \\
9 \text { samples }\end{array}$ \\
\hline $\begin{array}{l}\text { Criconema duplicivestitum } \\
\text { (Andrássy.1963) Raski \& Luc, } 1985\end{array}$ & $X$ & - & - \\
\hline $\begin{array}{l}\text { Criconemella azania } \\
\text { (Van den Berg.1979) Luc \& Raski.1981 }\end{array}$ & $\mathrm{X}$ & - & $\mathrm{x}$ \\
\hline $\begin{array}{l}\text { Criconemella sphaerocephala } \\
\text { (Taylor, 1936) Luc \& Raski,1981 }\end{array}$ & $\mathrm{x}$ & - & $\mathrm{x}$ \\
\hline Helicotylenchus labiodiscinus Sher. 1966 & $\mathrm{x}$ & - & - \\
\hline Helicotylenchus martini Sher.1966 & - & - & $\mathrm{X}$ \\
\hline Helicotylenchus pseudorobustus Sher, 1966 & - & - & $x$ \\
\hline $\begin{array}{l}\text { Hemicriconemoides brachyurus } \\
\text { (Loof.1949) Chitwood \& Birchfield.1957 }\end{array}$ & $\mathrm{x}$ & - & $x$ \\
\hline Hemicycliophora natalensis Loof \& Heyns. 1969 & $\mathrm{x}$ & - & - \\
\hline Hemicycliophora typica De Man,1921 & - & - & $\mathrm{X}$ \\
\hline Ogma naomiae spec. nov. & $x$ & $x$ & $x$ \\
\hline Ogma ueckermanni spec. nov. & $\mathrm{x}$ & $\mathrm{x}$ & $\mathrm{x}$ \\
\hline Paratrichodorus tansaniensis Siddiqi.1974 & - & - & $x$ \\
\hline Rotylenchus incultus Sher, 1965 & $\mathrm{X}$ & - & - \\
\hline Rotylenchus unisexus Sher, 1965 & $\mathrm{x}$ & - & $\mathrm{x}$ \\
\hline Scutellonema brachyurus (Steiner.1938) Andrássy.1958 & $\mathrm{x}$ & - & $\mathrm{x}$ \\
\hline Scutellonema commune Van den Berg \& Heyns, 1973 & - & - & $\mathrm{x}$ \\
\hline $\begin{array}{l}\text { Xiphinema elongatum } \\
\text { Schuurmans Stekhoven \& Teunissen.1938 }\end{array}$ & - & - & $\mathrm{X}$ \\
\hline Xiphinema mampara Heyns.1979 & - & - & $\mathrm{X}$ \\
\hline
\end{tabular}

$\mu \mathrm{m} ; \mathrm{R}=68 ; \mathrm{RSt}=16 ;$ ROes $=20 ;$ Rex $=24 ;$ $\mathrm{RV}=8 ; \mathrm{St} \% \mathrm{~L}=23,8 ; \mathrm{VL} / \mathrm{VB}=0,8$.

Paratype females - Muller's Pass $(n=10)$ : L $=401 \mu \mathrm{m} \pm 41,5(367-489) ; \mathrm{a}=6,7 \pm 1,0(5,6$ $-8,2) ; \mathrm{b}=3,2 \pm 0,3(3,0-3,9) ; \mathrm{V}=95 \pm 1,1(93$ -96); OV1 = 69: $80(n=2)$; stylet $=87,5 \mu \mathrm{m} \pm$ $3,9(80,9-94,0) ; \mathrm{R}=63-68 ; \mathrm{RSt}=16-22$; ROes = $21-27 ; \operatorname{Rex}=24-25 ;$ RV = $5-8$; $\mathrm{VL} / \mathrm{VB}=0,6 \pm 0,1(0,4-0,8) ; \mathrm{St} \% \mathrm{~L}=21,9$ $\pm 2,0(17,8-23,8)$.

Paratype females - Kamberg $(n=8): \mathrm{L}=498$ $\mu \mathrm{m} \pm 53,6(426-573) ; \mathrm{a}=8,0 \pm 0,9(6,8-9,1)$; $\mathrm{b}=3,6 \pm 0,4(3,1-4,2) ; \mathrm{o}=4,3: 5,2(n=2) ; \mathrm{V}$ $=95 \pm 1,5(93-98) ;$ OV $1=66 \pm 25,4(42-88)$; stylet $=94,5 \mu \mathrm{m} \pm 6,7(84,1-102,2) ; \mathrm{R}=63$ - 69; RSt $=15-20 ;$ ROes $=19-28 ; \operatorname{Rex}=22$ $-25 ; \mathrm{RV}=5-6 ; \mathrm{VL} / \mathrm{VB}=0,6 \pm 0,1(0,5-0,7)$; $\mathrm{St} \% \mathrm{~L}=19,1 \pm 2,7(15,7-22,8)$.
Paratypes females - Tendele $(n=7): \mathrm{L}=460$ $\mu \mathrm{m} \pm 26,3(409$ - 489); $\mathrm{a}=7,1 \pm 0,6(6,4-7,9)$; $\mathrm{b}=3,3 \pm 0,2(2,9-3,7) ; \mathrm{o}=6,5(n=1) ; \mathrm{V}=$ $94 \pm 0,4(93-95) ;$ OV1 $=65 \pm 8,2(57-78)$; stylet $=94,3 \mu \mathrm{m} \pm 4,4(90,0-102,0) ; \mathrm{R}=65$ - 69; RSt $=15-21 ;$ ROes $=19-28 ; \operatorname{Rex}=21$ - $24 ; \mathrm{RV}=6-7 ; \mathrm{VL} / \mathrm{VB}=0,6 \pm 0,1(0,5-$ $0,7) ; \mathrm{St} \% \mathrm{~L}=20,5 \pm 1,3(18,7-22,9)$.

Juveniles - Muller's Pass $(n=2): \mathrm{L}=357 \mu \mathrm{m}$ : $399 \mu \mathrm{m} ; \mathrm{a}=5,7: 8,8 ; \mathrm{R}=76$.

Female: Body curved slightly ventrad. Lip region with one annulus consisting of a wide part separated from the first body annulus by a 3,0 $\mu \mathrm{m}$ high neck; lip annulus diameter 19,7 um $\pm 1,7(17,6$ to 22,8$)$, greater than first body annulus diameter which is $17,6 \mu \mathrm{m} \pm$ $1,5(14,3$ to 20,9$)$; two succeeding body annuli diameters $23,9 \mu \mathrm{m} \pm 2,5$ (19,5 to 29,0$)$ and $30,7 \mu \mathrm{m} \pm 2,4(26,5$ to 35,3 ) respectively; margin of lip and first two body annuli 

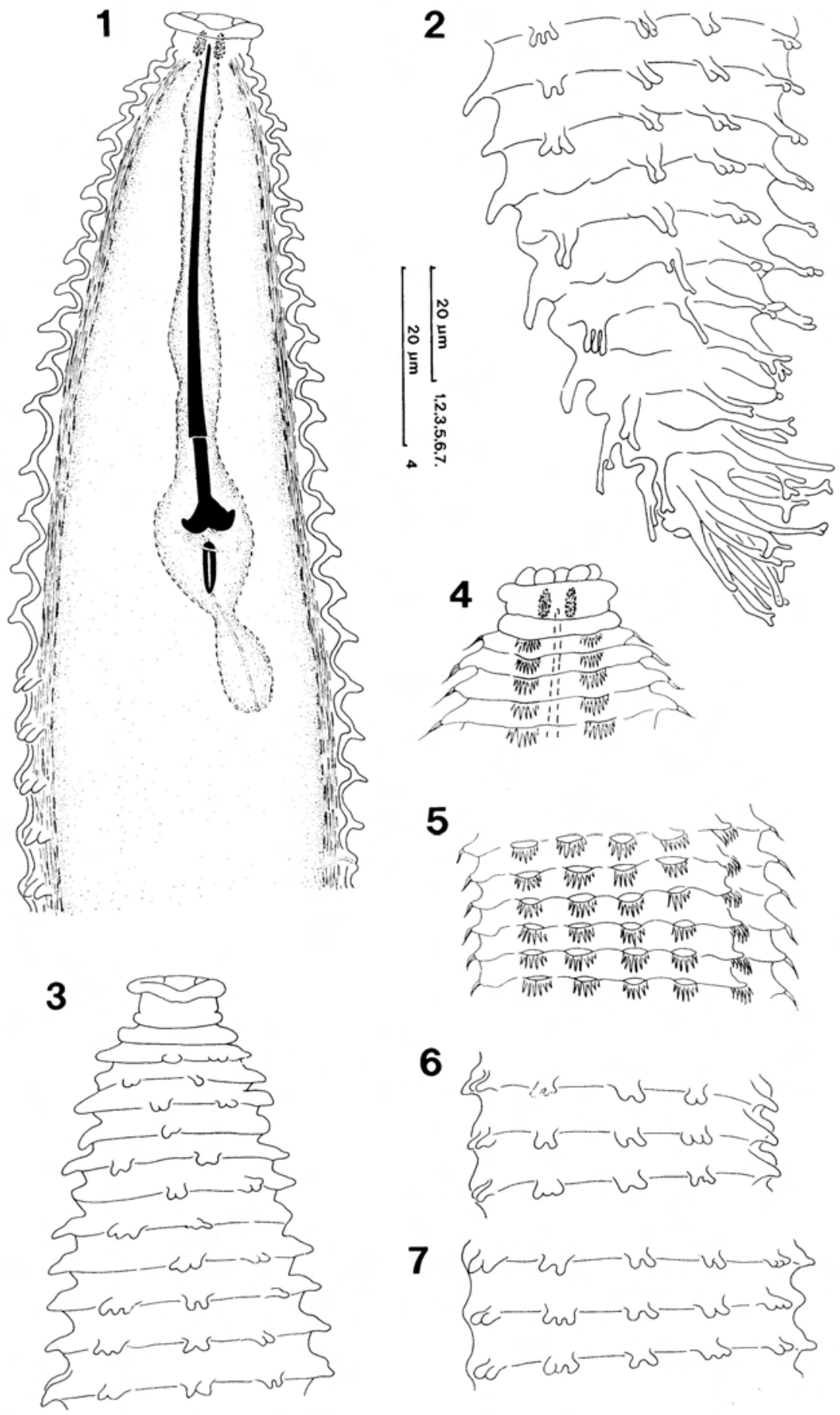

Fig. 1. Ogma naomiae spec. nov.

1. Anterior part of holotype female body. 2. Posterior part of holotype female body. 3. External view of anterior part of holotype female body showing haphazard arrangement of scales. 4 . Lip region of juvenile. 5. Juvenile cuticle at midbody 6 . Holotype female cuticle at midbody. 7. Holotype female cuticle just posterior to base of oesophagus. 


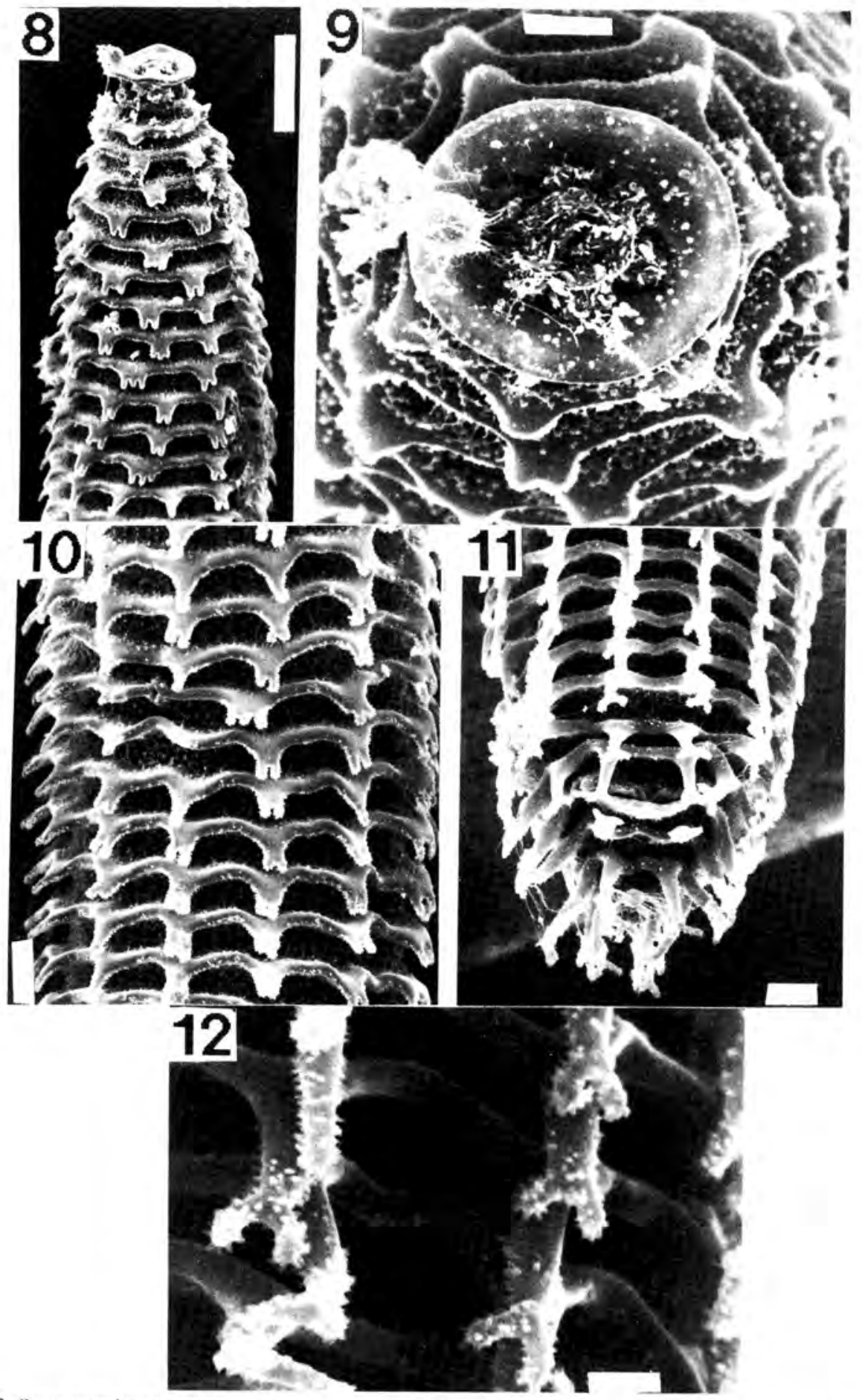

Fig. 2. Ozma natmiac spec, nov.

8. Anterior part of female body. 9. En face view of female lip region. 10. Female cuticle at level of excretory pore. 11. Posterior part of female body. 12. Protuberances on scale tips. (Bar $=5 \mu \mathrm{m}:$ in 9.12: 10 $\mu \mathrm{m}$ : in 10, 11:20 $\mu \mathrm{m}$ : in 8). 

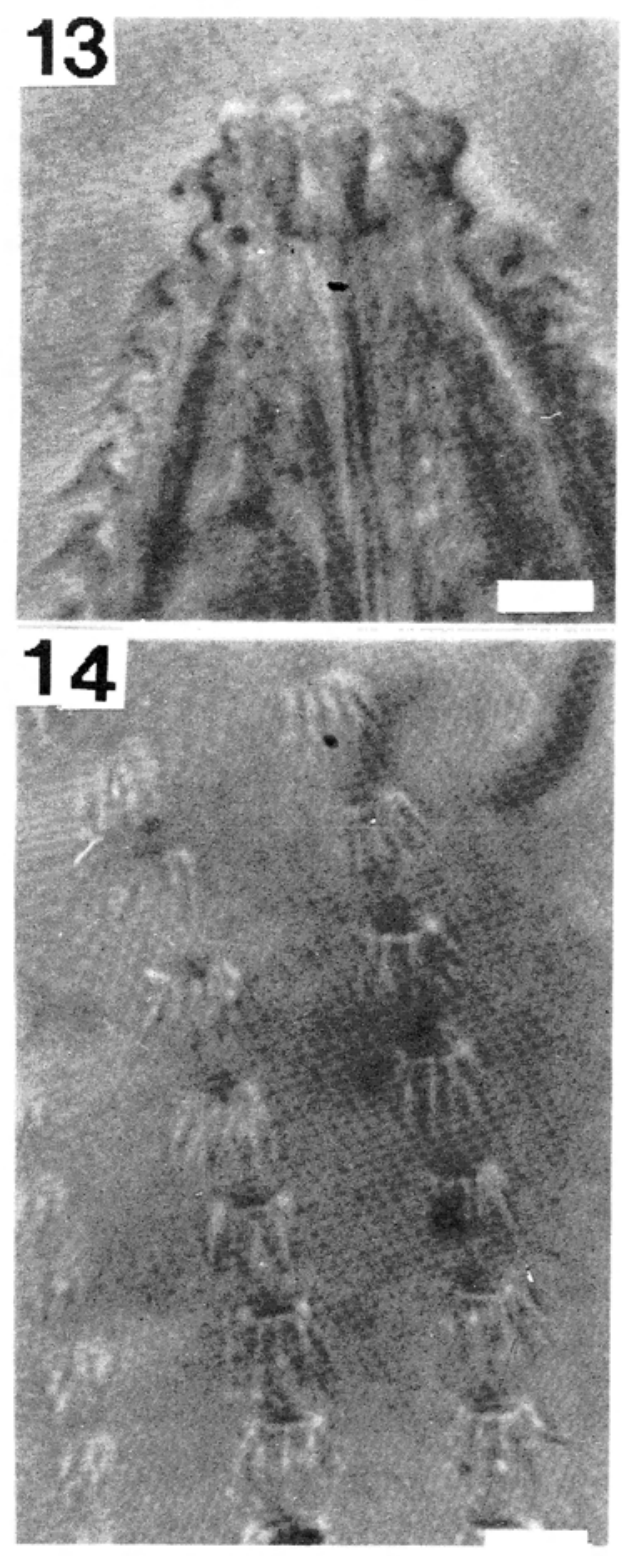

Fig. 3. Ogma naomiae spec. nov.

13. Juvenile lip region. 14. Juvenile scales. (Bar $=5 \mu \mathrm{m}$ : in 13,14$)$.

slightly wave-like; lip and first body annulus rounded, projecting outward and second body annulus is slightly retrorse; all other body annuli well retrorse; labial disc area not protruding markedly above lip annulus; in en face view labial disc appears rounded and raised above six pseudolips. First nine to 10 body annuli with varying number of scales, arranged haphazardly and not in rows; scales on first few body annuli rounded; further posteriorly all scales have mostly two. rounded, finger-like projections, one, three and four occasionally present; 10 to 12 longitudinal rows of scales at midbody, 13 rows in one female; just anterior to vulva the scales are much longer, gradually becoming longer and more slender toward tail tip, especially on ventral side of body where most scales are bifurcate; all scales with minute protuberances mainly on outer edges and tips of processes, difficult to see under light microscope. Anus completely obscured by projections mostly with debris in between. Vulva appears as two elongated lips in lateral view. Width of annuli at midbody $7,8 \mu \mathrm{m} \pm 1,4(5,5$ to 11,8$)$. Excretory pore situated from anterior to posterior to base of oesophagus, 144 $\mu \mathrm{m} \pm 19,8$ (93 to 166 ) from anterior end of body, seen in a few specimens only. Width at midbody $62,9 \mu \mathrm{m} \pm 5,3(49,6$ to 71,3$)$ and at the excretory pore $66,6 \mu \mathrm{m} \pm 2,8(62,1$ to $72,0)$. Hemizonid not seen. Stylet long and slender with slightly cupped basal knobs, the latter $10,9 \mu \mathrm{m} \pm 0,9(8,8$ to 12,1$)$ wide and 4,1 $\mu \mathrm{m} \pm 0,5(3,3$ to 5,1$)$ high. Metenchium 76,3 $\mu \mathrm{m} \pm 5,6(66,5$ to 85,3$)$ long and telenchium $17,3 \mu \mathrm{m} \pm 0,9(15,4$ to 18,7$)$ long. Spermatheca not seen; egg present in holotype female. Ovary very long sometimes reaching oesophagus or stylet; a few specimens with ovary tips reflexed. Posterior end of body rounded.

Male: Not found.

Juvenile: Four juveniles found, but only two could be measured. Posterior part of stylet obscure. Lip region with one annulus, almost the same diameter as first body annulus, 13,2 $\mu \mathrm{m}: 14,0 \mu \mathrm{m}$ and $14,3 \mu \mathrm{m}: 14,0 \mu \mathrm{m}$ respectively; succeeding two body annuli diameters $18,7 \mu \mathrm{m}$ and $23,2 \mu \mathrm{m}(n=1)$ respectively; labial disc area prominent above lip annulus with four distinct lobes. Fourteen to 16 longitudinal rows of scales at midbody not haphazardly arranged on anterior part; scales become longer toward tail tip each with five to seven sharply pointed finger-like processes. 

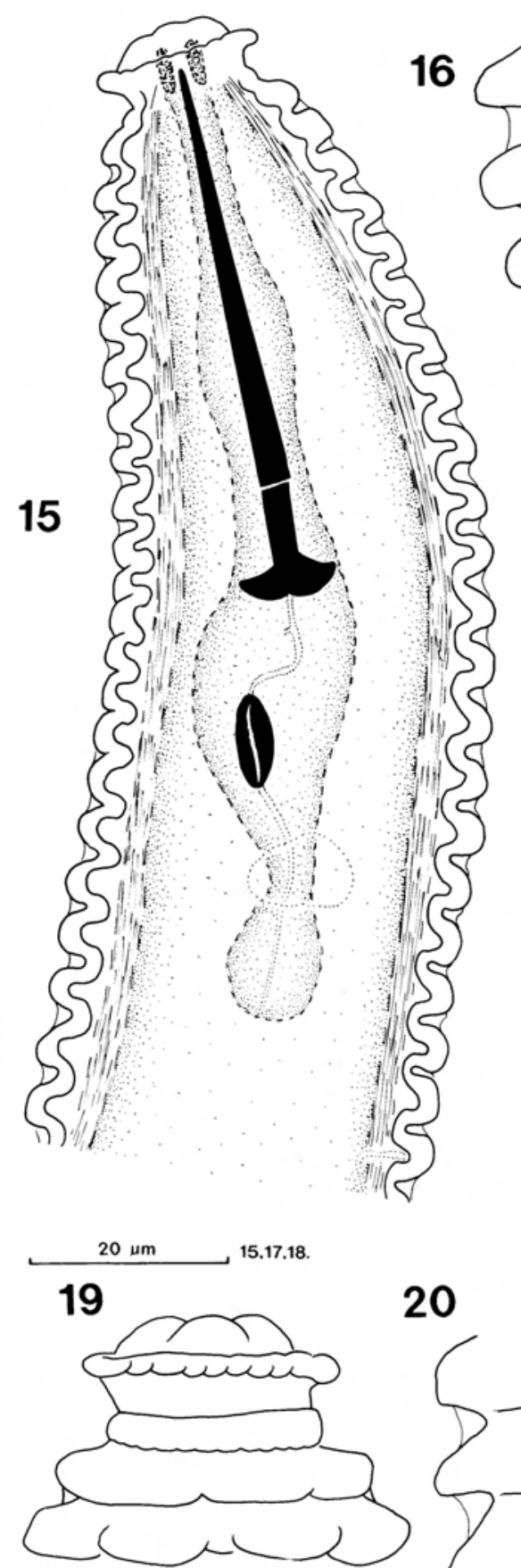

$20 \mu \mathrm{m}$

20

17

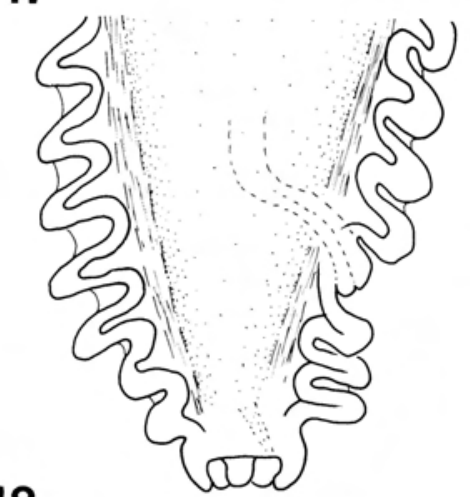

18

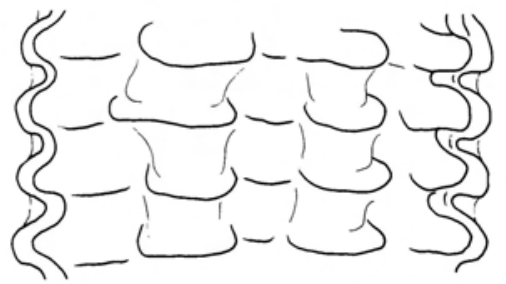

Fig. 4. Ogma ueckermanni spec. nov.

15. Anterior part of holotype female body. 16. Posterior part of female body, external view. 17. Posterior part of holotype female body, internal view. 18. Holotype female cuticle just posterior to base of oesophagus. 19. Holotype female lip region enlarged. 20. Holotype female cuticle just anterior to vulva. 


\section{Material examined}

Type locality: Natal: Newcastle dist., 14 October 1990, holotype female (slide 27236), nine paratype females and four paratype $\mathrm{jj}$ (slides 27236 to 27238), leg. N.H. Buckley, collected from indigenous vegetation, next to the road leading to the farmhouse on the farm "Moorefield", about $35 \mathrm{~km}$ south west of Newcastle, on the gravel road to Memel in the Muller's Pass ( $27^{\circ} 52^{\prime} \mathrm{S}$ lat. $29^{\circ} 44^{\prime} \mathrm{E}$ long.) in a sandy loam soil ( $8 \%$ clay, $12 \%$ silt, $80 \%$ sand). Height above sea-level $1500 \mathrm{~m}$, annual rainfall $850 \mathrm{~mm}$. One paratype female (slide 27239) collected from the same locality below the waterfall in a sandy loam soil ( $8 \%$ clay, $20 \%$ silt, $72 \%$ sand), also from indigenous vegetation.

Other localities: Giant's Castle Nature Reserve, 22 January 1991,11 poorly preserved paratype females (slides 27249, 27253 to 27255) (not measured), leg. E.A. Ueckermann, collected from a fern and Protea caffra Meisn. in the Reserve $\left(29^{\circ} 15^{\prime} \mathrm{S}\right.$ lat. $29^{\circ} 32^{\prime} \mathrm{E}$ long.) from a loamy sand soil (8\% clay, $7 \%$ silt, $85 \%$ sand). Height above sealevel $2100 \mathrm{~m}$, annual rainfall $900 \mathrm{~mm}$, soil pH 5,0. Kamberg Nature Reserve, 14 January 1991, 34 paratype females (slides 27240 to 27247), leg. E.A. Ueckermann, collected from Leucosidea sericea Eckl. \& Zeyh. in the Reserve $\left(29^{\circ} 24^{\prime} \mathrm{S}\right.$ lat. $29^{\circ} 40^{\prime} \mathrm{E}$ long.) from a sandy soil (3\% clay, $7 \%$ silt, $90 \%$ sand). Height above sea-level $2000 \mathrm{~m}$, annual rainfall $900 \mathrm{~mm}$, soil pH 5,3. Royal Natal National Park, 24 January 1991, 39 paratype females (slides 27256 to 27265 ), leg. E.A. Ueckermann, collected in the vicinity of the Tendele Rest Camp ( $28^{\circ} 42^{\prime} \mathrm{S}$ lat. $28^{\circ} 56^{\prime} \mathrm{E}$ long.) from the following plants: Alsophila dregei (Kunze) R. Tryon., Buddleja salviifolia (L.) Lam., Cussonia paniculata Eckl. \& Zeyh., Dais cotinifolia L., Euclea crispa (Thunb.) Gürke, Heteromorpha arborescens (Spreng.) Cham. \& Schlechtd., Leucosidea sericea Eckl. \& Zeyh., Podocarpus falcatus (Thunb.) R. Br. ex Mirb., Protea caffia Meisn., Pteridium aquilinium (L.) Kuhn, from a predominantly loamy sand soil $(5 \%$ clay, $7 \%$ silt, $88 \%$ sand). Height above sea- level $1500 \mathrm{~m}$, annual rainfall $1100 \mathrm{~mm}$, soil $\mathrm{pH} 5,0$.

Diagnosis and relationship: Ogma naomiae spec. nov. females are characterised by having 10 to 12 longitudinal rows of scales on 63 to 69 retrorse annuli; scales haphazardly arranged on first nine to 10 body annuli; scales rounded anteriorly then mostly with two projections posteriorly; scales with one, three and four projections also present; scales become longer toward posterior end but on ventral side of body they are longer, more slender and bifurcate obscuring vulva and anus; all scales with minute protuberances on outer edges; lip region with one annulus which has a greater diameter than first body annulus with labial area not projecting markedly above lip annulus. Juveniles with 14 to 16 longitudinal rows of scales on 73 to 76 retrorse body annuli not haphazardly arranged on anterior part; scales bear five to seven sharply pointed finger-like processes each; scales become slightly longer toward tail tip; lip annulus with same diameter as first body annulus.

Ogma naomiae spec. nov. is closely related to $O$. coronatum described by SchuurmansStekhoven \& Teunissen (1938) from the Albert National Park in Zaîre (Belgian Congo) from altitudes of $1845 \mathrm{~m}$ to $2300 \mathrm{~m}$ and redescribed by De Coninck (1945), but differs from this species in the following: female with more body annuli (63 to $69 v s 44$ to 54 ); 10 to 12 longitudinal rows of scales vs 16 to 20 arranged more haphazardly anteriorly; scales with more prominent projections; vulva situated slightly more posteriorly $(\mathrm{V}=$ 93 to 98 vs 89 to 92 ); lip and first body annuli with smaller diameters (17,6 to $22,8 \mu \mathrm{m}$ and 14,3 to $20,9 \mu \mathrm{m} v s 22,5$ to $26,5 \mu \mathrm{m}$ and 17,7 to $24,0 \mu \mathrm{m}$ respectively). Juveniles with more body annuli (76 vs 54 to 57 ) and completely different scales; according to Fig. 29 of De Coninck (1945) the scales appear similar to those of the female.

From the closely related species $O$. chrisbarnardi described by Heyns (1970) and recently reported again by the present author (Van den Berg 1991) it differs mainly 

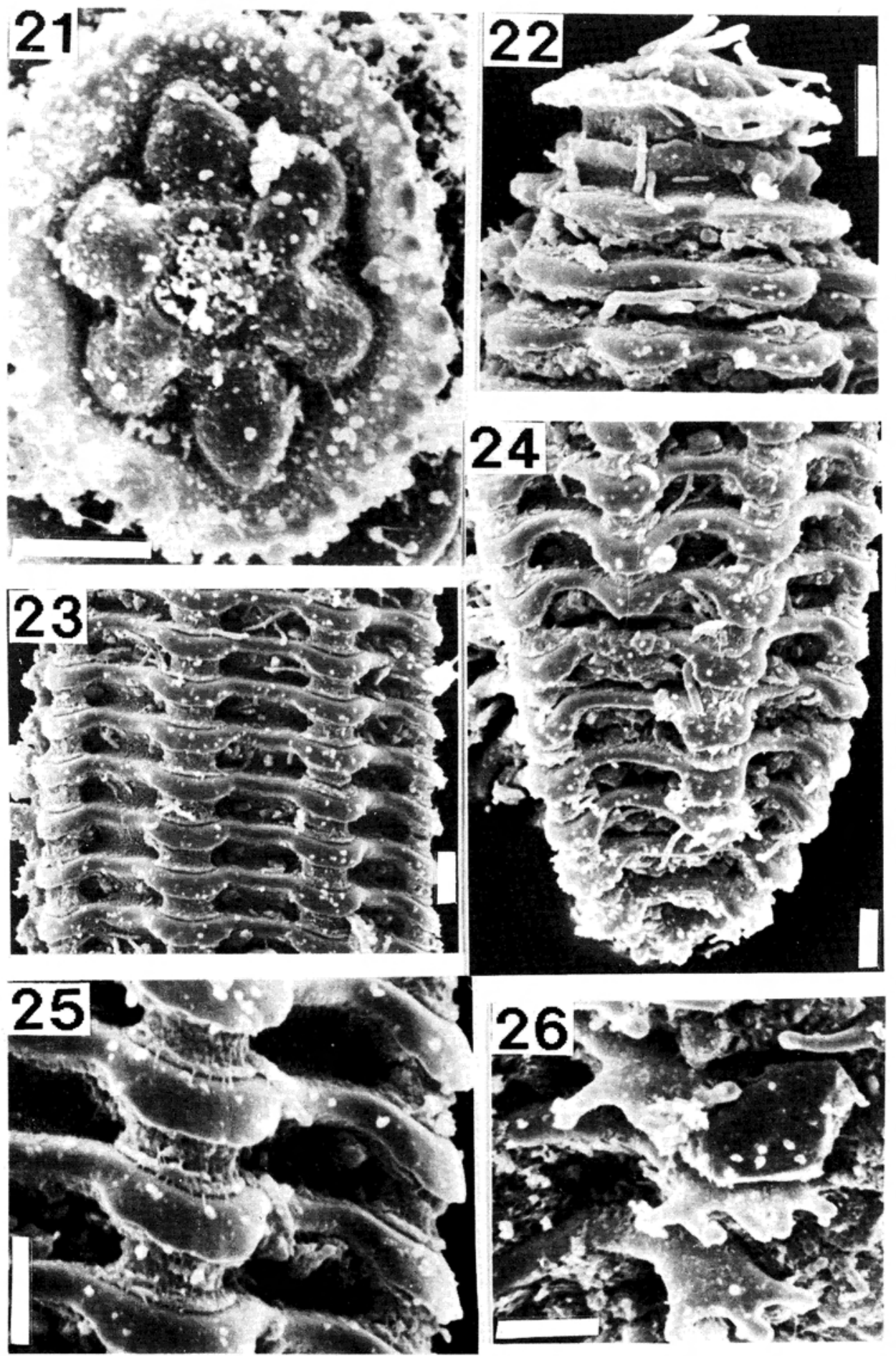

Fig 5. Ogma ueckermanni spec. nov.

21. En face view of female lip region. 22. Female lip region, lateral view. 23. Female cuticle at midbody. 24. Posterior part of female body. 25. Scales on female cuticle enlarged. 26. Branched scales on posterior part of body. (Bar $=5$ $\mu \mathrm{m}$; in 21 to 26 ). 
in the form of the scales (two to four pronged on whole body i's mostly rounded and some two-tipped anterior to vulva): 10 to 12 longitudinal rows of scales at midbody is eight; scales with minute protuberances on outer edges is minutely serated edges.

Ogma ueckermanni spec. nov. (Figs 4-5)

\section{Measurements}

Holotype female - Giant's Castle: $\mathrm{L}=366$ $\mu \mathrm{m} ; \mathrm{a}=8,6 ; \mathrm{b}=3,6 ; \mathrm{c}=83,0 ; \mathrm{o}=4,1 ; \mathrm{V}$ $=94,6$; stylet $=54,4 \mu \mathrm{m} ; \mathrm{R}=65 ; \mathrm{RSt}=13$; ROes $=22 ; \operatorname{Rex}=24 ; \mathrm{RV}=5 ; \mathrm{RVan}=3$; $\operatorname{Ran}=1 ; \mathrm{VL} / \mathrm{VB}=0,63 ; \mathrm{St} \% \mathrm{~L}=14.9$.

Paratype females - Giant's Castle $(n=15): \mathrm{L}$ $=331 \mu \mathrm{m} \pm 32,3(283-389) ; \mathrm{a}=7,6 \pm$ $0,7(6,3-8,6) ; b=3,5 \pm 0,3(2,9-4,2) ; c=$ $91,9 \pm 19,4(64,1-112,3) ; \quad o=5,6 \pm 1,6(4,1-$ $7,3) ; \mathrm{V}=94 \pm 0,8(92-95) ; \mathrm{OVI}=55 \pm$ $6,7(42-62) ;$ stylet $=54,6 \mu \mathrm{m} \pm 2,0(49,3-$ $56,9) ; \mathrm{R}=60-67 ; \mathrm{RSt}=11-15 ;$ ROes $=$ $16-23 ; \operatorname{Rex}=21-24 ; \mathrm{RV}=4-6 ; \mathrm{RVan}=$ 2 - 4; Ran $=1 ; \mathrm{VL} / \mathrm{VB}=0,67 \pm 0,1(0,50-$ $0,75) ; \mathrm{St} \% \mathrm{~L}=16,6 \pm 1,5(13,7-18,6)$.

Females - Kamberg $(n=2): \mathrm{L}=313 \mu \mathrm{m}: 306$ $\mu \mathrm{m} ; \mathrm{a}=8,1: 6,5 ; \mathrm{b}=3,6: 3,5 ; \mathrm{V}=93: 92$; OVI $=42:-;$ stylet $=54,4 \mu \mathrm{m}: 55.9 \mu \mathrm{m} ; \mathrm{R}=$ $61: 62 ; \mathrm{RSt}=12: 15 ;$ ROes $=17: 21 ;$ Rex $=$ $21:-; \mathrm{RV}=6 ; \mathrm{VL} / \mathrm{VB}=-: 0,73 ; \mathrm{St} \% \mathrm{~L}=17,4$ $: 18,3$.

Female - Tendele $(n=1): \mathrm{L}=410 \mu \mathrm{m} ; \mathrm{a}=$ 7,$2 ; \mathrm{b}=3,9 ; \mathrm{c}=34,8 ; \mathrm{V}=91 ; \mathrm{OV} 1=79 ;$ stylet $=60,7 \mu \mathrm{m} ; \mathrm{R}=60 ; \mathrm{RSt}=11 ; \mathrm{ROes}=17 ; \mathrm{Rex}$ $=20 ; \mathrm{RV}=8 ; \mathrm{RVan}=4 ; \mathrm{Ran}=3 ; \mathrm{VL} / \mathrm{VB}=$ 0,$93 ; \mathrm{St} \% \mathrm{~L}=14,8$.

Female: Body almost straight, at most curved slightly ventrad. Lip region with one annulus, diameter $17,8 \mu \mathrm{m} \pm 0,9(16,2$ to 19,1$)$; first body annulus with a diameter of $15,5 \mu \mathrm{m} \pm$ $1,0(14,0$ to 17,6$)$; labial area raised slightly above lip annulus with six pseudolips and no submedian lobes; labial disc not distinctly raised above pseudolips; margin of lip annulus with rounded tooth-like projections. Margin of first body annulus slightly scalloped. Second and third body annuli diameters 22,7 $\mu \mathrm{m} \pm 1.9(19,5$ to 25,4$)$ and $27,0 \mu \mathrm{m} \pm$ $1,9(23,2$ to 29,4$)$ respectively (Tendele specimen - 26,8 $\mu \mathrm{m}$ and $32,3 \mu \mathrm{m}$ ). From second body annulus all body annuli are well retrorse with eight rows of rounded scales at midbody, gradually becoming longer toward posterior part of body, scales slightly longer on ventral side of body from about level of vulva; posterior scales more broadly rounded, irregular with knoblike projections or even two to four- pronged (Fig. 26). Protruding part of annulus smooth, recessed part roughly sculptured (seen only with SEM); recessed part of annulus extended to follow the outline of the scale almost forming a pillar between two succeeding scales (Fig. 25). Width of annuli at midbody $5,5 \mu \mathrm{m} \pm 0,8(4,0$ to 6,6$)$. Excretory pore mostly situated from two to five annuli posterior to base of oesophagous, $113 \mu \mathrm{m} \pm 9.6$ (93 to 127 ) from anterior end of body. Width at midbody 44,3 $\mu \mathrm{m} \pm 4,6(34,2$ to 50.0$)$ and at excretory pore $42.0 \mu \mathrm{m} \pm 3.2$ (37.5 to 47,8$)$. Hemizonid not seen. Stylet well developed with cupped basal knobs, the latter $9,8 \mu \mathrm{m} \pm 0,6(8,8$ to $10,7)$ wide and $3,8 \mu \mathrm{m} \pm 0,4(2,9$ to 4,4$)$ high. Opening of dorsal oesophageal gland $3,0 \mu \mathrm{m}$ $\pm 0,9(2,2$ to 4,0$)$ from base of stylet knob ( $n$ =3). Metenchium 42,1 $\mu \mathrm{m} \pm 1.7(37,9$ to 44,1$)$ long and telenchium 12,6 $\mu \mathrm{m} \pm 0,7$ (11,0 to $13,6)$ long. Spermatheca round and filled with roundish sperm, three annuli long, situated seven to 10 annuli anterior to vulva. Dorsal vulval lip forming a flap. Ovary reflexed in several specimens. Posterior part of body rounded. Anus seen in a few specimens, situated on last body annulus (third last in Tendele female); tail $3,8 \mu \mathrm{m} \pm 0,7(2,9$ to 4,4$)$ long $(n=5)$, (Tendele female 11,8 $\mu \mathrm{m})$.

Male: Not found.

Juvenile: Not found.

\section{Material examined}

Type locality: NATAL: Giant's Castle Nature Reserve. 22 January 1991, holotype female (slide 27248), 15 paratype females (slides 27248 to 27252), leg. E.A. Ueckermann, collected from a fern and Protea caffica Meisn. in the reserve $\left(29^{\circ} 15^{\prime} \mathrm{S}\right.$ lat. 
$29^{\circ} 32^{\prime}$ E long.) from a loamy sand soil (8 \% clay, $7 \%$ silt, $85 \%$ sand). Height above sealevel $2100 \mathrm{~m}$, annual rainfall $900 \mathrm{~mm}$, soil pH 5,0 .

Other localities: Kamberg Nature Reserve, 14 January 1991, three poorly preserved females, leg. E.A. Ueckermann, collected from Lencosidea sericea Eckl. \& Zeyh. from a sandy soil (3\% clay, $7 \%$ silt, $90 \%$ sand). Height above sea-level $2000 \mathrm{~m}$, annual rainfall $900 \mathrm{~mm}$, soil pH 5,3. Royal Natal National Park, 24 January 1991, one poorly preserved female, leg. E.A. Ueckermann, collected near the Tendele rest camp $\left(28^{\circ}\right.$ $42^{\prime} \mathrm{S}$ lat. $28^{\circ} 56^{\prime} \mathrm{E}$ long.) from virgin Bergveld from a loamy sand soil (5\% clay, $7 \%$ silt, $88 \%$ sand). Height above sea-level $1500 \mathrm{~m}$, annual rainfall $1100 \mathrm{~mm}$, soil pH 5,0.

Diagnosis and relationship: Ogma ueckermanni spec. nov. females are characterised by eight longitudinal rows of rounded scales on 60 to 67 body annuli becoming longer toward tail tip where they bear knob-like or two to four-pronged processes; roughly sculptured recessed part of annulus extended to follow the outline of the scale almost forming a pillar between two succeeding scales; one lip annulus with a greater diameter than first body annulus; raised labial area with six pseudolips and no sub-median lobes; lip annulus margin with rounded tooth-like projections and a 49,3 to $60,7 \mu \mathrm{m}$ long stylet.

From the closely related $O$. dracomontanum (Van den Berg, 1983) Siddiqi, 1986, also described from the Giant's Castle Nature Reserve O. ueckermanni spec. nov. differs in the following: eight longitudinal rows of scales is six; extension of recessed area of annulus to follow outline of scale vs no extension; more body annuli (60 to 67 vs 53 to 59 ) and projections on posterior part of body shorter. This new species is also seperated from all other Ogma species with eight longitudinal scale rows by the presence of the annulus extension below the scales and in most cases by not having a pointed tail: Furthermore it is separated by such characters as stylet length, number of body annuli, number of lip annuli and form of scales.

\section{Acknowledgements}

The author wishes to thank the Natal Parks Board for allowing the samples to be collected. The following persons from the Plant Protection Research Institute are thanked: Mrs. N.H. Buckley for technical assistance, Mrs. H.C. Coetzee for typing the manuscript, Dr. K.P.N. Kleynhans for reading the manuscript and Mr. H. van Tonder for the SEM photographs.

\section{References}

DE CONINCK, L. 1945. Sur la variabilité de Criconema cobbi (Micoletzki, 1925) et la systématique du genre Criconema Hofmänner \& Menzel, 1914 (Criconematinae: Nematoda) avec des données nouvelles sur quelques espèces du genre. Bulletin Musée royal d' Histoire naturelle de Belgique 24: 1 - 32.

GOODEY, T. 1951. Laboratory methods for work with plant and soil nematodes. Ministry of Agriculture and Fisheries, Technical Bulletin No.2. His Majesty's Stationary Office, London.

HEYNS, J. 1970. South African Criconematinae. Part 2. Genera Criconema, Hemicriconemoides and some Macroposthonia (Nematoda). Phytophylactica 2: 129 - 136.

SCHUURMANS-STEKHOVEN, J.H. and TEUNISSEN, R.J.H. 1938. Nematodes libres Terrestres. Exploration du Parc National Albert. Mission G.F. de Witte (1933 - 1935) 22: 1 - 229.

VAN DEN BERG, E. 1991. New and known Criconemella and Ogma species from northern Natal coastal sandy soils (Criconematinae: Nemata). Phytophylactica 23: 157 - 165. 